\title{
Evaluation of the Nutrient Composition of Fruits Selected from Different Markets in Lagos, Nigeria together with Heavy Metals Contents
}

\section{Bolawa O.E. ㅍ, Akintobi O.J.}

Department of Biochemistry, University of Lagos, Akoka, Nigeria, West Africa, Africa

$\downarrow$ Corresponding author email: olatundunebolawa@yahoo.com

Plant Gene and Trait, 2019, Vol.10, No.1 doi: $\underline{10.5376 / \text { pgt.2019.10.0001 }}$

Received: 26 Aug., 2019

Accepted: 23 Oct., 2019

Published: 09 Dec., 2019

Copyright (C) 2019 Bolawa and Akintobi, This is an open access article published under the terms of the Creative Commons Attribution License, which permits unrestricted use, distribution, and reproduction in any medium, provided the original work is properly cited.

Preferred citation for this article:

Bolawa O.E., and Akintobi O.J., 2019, Evaluation of the nutrient composition of fruits selected from different markets in lagos, Nigeria together with heavy metals contents, Plant Gene and Trait, 10(1): 1-6 (doi: 10.5376/pgt.2019.10.0001)

\begin{abstract}
Fruits are a form of staple food for humans obtained naturally. They contain various quantities of essential nutrients in the right proportion. Intake of fruits in the diet is usually a very heathy lifestyle as fruits prevents disease and keeps us healthy. Ingestion of trace amount of heavy metals through fruits leads to bioaccumulation producing serious health hazards. The aim of the study is to investigate the amount of heavy metals in fruits obtained from different markets in Lagos, Nigeria.
\end{abstract}

Keywords Fruits, Lead, Cadmium, Chromium, Zinc, Nickel

\section{Introduction}

Fruits are very important components of our diet. Consumption of fruits helps us to live a healthy life. Fruits prevent all diseases and keep us energetic and active throughout our life time even up to our ripe old age. The importance of fruits in human life is described in table 1 below. Fruits are rich in various vitamins, minerals and nutrients (Table 1). The natural uptake of vitamins and minerals in humans is through the ingestion of fruits. Diet rich in fruits are good sources of anti-oxidants and dietary fibre (pectin). These are protective against chronic diseases such as cancer and cardiovascular disease (Wang et al., 1996).

Recent dietary guidelines highly recommend the consumption of fruits. Some fruits, such as Mulberry are being used as a folk remedy to cure diabetes, hypertension, oral and dental disease, arthritis and anemia (Ozgen et al., 2009)

Fruits deserve special attention because of the important influence on human health. Generally speaking, in $90 \%$ of the world population, fruits represent the primary source of the health care. The effectiveness of fruits is associated with their individual constituents such as vitamins, glycosides, minerals etc. (Jabeen et al., 2010)

Fruits can be contaminated by heavy metals during cultivation. Rapid industrialization has increased the levels of heavy metals in developing countries (Sharma et al., 2009).

Industrial uses of metals have introduced great amount of toxic metals into the environment. Heavy metals are toxic in animals, human and plant (Fotakis and Timbre, 2005). The use of fertilizers, herbicides and insecticides by farmers leads to heavy metals contamination of soil plants and fruits. Ingestion of heavy metals through food can cause accumulation, leading to serious health hazards. The quality of fruits products is diminished with increase in the concentration of toxic compounds, pollutants such as pesticides and heavy metals. Heavy metals are toxic and some of them are carcinogenic (Krejpcio and Gamedci, 1996). Increasing knowledge about the toxic effect of heavy metals on human health has led to closer examination of these metals in agricultural products (ISHS, 2001). Therefore, monitoring of heavy metals in food leads to the improvement of food safety and warns consumers of potential food scares as well as facilitates the evaluation and prediction of future health hazards. Monitoring also provides information on the levels of environmental pollution in the country (Doghein, 2004). 
Plant Gene and Trait 2019, Vol.10, No.1, 1-6

http://genbreedpublisher.com/index.php/pgt

Table 1 Importance of fruits in human life

\begin{tabular}{ll}
\hline Fruits & Importance \\
\hline Apple & Rich in iron, useful in acute and chronic dysentery among children, stomach disorders, headache, \\
& heart disease, maintain blood pressure, dry hacking cough, removing kidney stone, mouth \\
& cleaning properties and makes the body strong \\
& Rich in potassium, protein, vitamins, useful in intestinal disorders, dysentery, arthritis and gout \\
& patients, anemia, kidney and liver disorders. Paste of ripe banana gives relief of burns and wound. \\
Banana & Rich in citric acid and vitamin c. Useful as a good cleansing agent. Destroy toxins in the body. \\
& Cure of gum disease, catarrh, constipation, diarrhea, obesity, different hemorrhage, useful for food \\
Lemon & relaxation. \\
& Rich in vitamins, minerals. Useful in treatment of night blindness, loss of weight, diabetes, seeds \\
& are useful in diarrhea, throat infections, constipation, eye infections. \\
Mango & Rich in calcium, phosphorus, vitamins. Useful in skin, diabetic patients, acidosis, eye disease, \\
obesity, liver, diarrhea & Rich in vitamins, minerals. Useful in treatment of sore throat, fever, cystitis, edema, liver and \\
Tomato & $\begin{array}{l}\text { abdominal disorders, plethora, asthma, thirst, hunger loss of body weight, curing of pain, gastric } \\
\text { trouble, enlarged liver and spleen. }\end{array}$ \\
Date &
\end{tabular}

The aim of this paper is to monitor the levels of heavy metals in fruits obtained from Lagos metropolis, as well as evaluate the level of environmental pollution in the country.

\section{Materials and methods}

\subsection{Samples collection}

Fresh fruits samples were collected from different markets in the Lagos metropolis. Sampling was done at random from different retailers within the market. A total of ten fruits varieties were collected in pairs from each of these markets' areas.

\subsection{Sample preparation}

The fruits samples were washed and rinsed with distilled water. They were sliced to small pieces and oven dried at $150^{\circ} \mathrm{C}$ for 48 hours. The dried samples were grounded into powder form and stored in polythene bags, ready for digestion.

\subsection{Sample digestion}

$10 \mathrm{~g}$ of each dried sample was weighed and digested in $20 \mathrm{~m}$ of $3: 1$ mixture of nitric acid and perchloric acid using a hot plate till a clear solution was obtained.

The solution was cooled and made up to $100 \mathrm{ml}$ with distilled water (AOAC, 2000). The digested samples were filtered and transferred to clean dried bottles for chemical analysis using the atomic absorption spectrophotometer (Perkin Elmer Analyst).

\section{Results}

From the results obtained, it can be seen that moisture makes up $80-90 \%$ of fruits (Table 2). Water melon has the highest moisture content (91.3\%) while the pear fruit is lowest in moisture content (66.4\%).

Carbohydrate content in fruits is between $6-15 \%$. Banana has the highest carbohydrate content $(20.50 \%)$ while water melon has the lowest carbohydrare content $(6.10 \%)$. For movement of the bowels, pears and banana fruits are quite good for they have a high percentage of crude fibre $(5.23 \%$ and $3.20 \%)$ respectively). Pears fruits are highest in protein content $(1.55 \%)$ followed by water melon $(1.00 \%)$ and thus are particularly good for vegetarians.

Lead ranges from $0.01 \mathrm{mg} / \mathrm{kg}$ (tangerine) to $0.12 \mathrm{mg} / \mathrm{kg}$ (in carrot). Chromium ranges from $0.01 \mathrm{mg} / \mathrm{kg}$ in pears to $0.11 \mathrm{mg} / \mathrm{kg}$ in apples. 
Plant Gene and Trait 2019, Vol.10, No.1, 1-6

http://genbreedpublisher.com/index.php/pgt

Table 2 Proximate analysis of fruits

\begin{tabular}{lllllll}
\hline Fruits samples & Moisture $\%$ & Ash $\%$ & Fat $\%$ & Protein $\%$ & Crude fibre \% & Carbohydrate \% \\
\hline Mango & 81.60 & 0.35 & 0.45 & 0.48 & 1.20 & 15.85 \\
Tangerine & 82.30 & 0.47 & 0.39 & 0.96 & 5.23 & 13.00 \\
Pear & 66.40 & 1.42 & 12.95 & 1.55 & 5.23 & 12.73 \\
Pineapple & 84.40 & 0.60 & 0.12 & 0.54 & 1.40 & 12.85 \\
Apple & 87.10 & 0.55 & 0.30 & 0.58 & 1.45 & 9.94 \\
carrot & 85.40 & 0.97 & 0.24 & 0.93 & 2.80 & 9.58 \\
Water melon & 91.30 & 0.46 & 0.42 & 1.00 & 0.68 & 6.10 \\
Orange & 84.20 & 0.70 & 0.16 & 0.82 & 2.40 & 11.64 \\
Paw paw & 87.00 & 0.50 & 0.28 & 0.48 & 1.20 & 10.93 \\
Banana & 74.10 & 0.57 & 0.43 & 1.20 & 3.20 & 20.50 \\
\hline
\end{tabular}

Cadmium was not detected in oranges and it is minimal in paw paw, water melon and carrot. It is highest in apples $(0.14 \mathrm{mg} / \mathrm{kg})$. Copper is lowest in oranges $(0.33 \mathrm{mg} / \mathrm{kg})$ and highest in pear $(1.16 \mathrm{mg} / \mathrm{kg})$. Pawpaw and pineapple are rich in zinc $(7.71 \mathrm{mg} / \mathrm{kg}$ and $6.60 \mathrm{mg} / \mathrm{kg}$ respectively while carrot has a low level of zinc $(0.28 \mathrm{mg} / \mathrm{kg})$. Pear and banana are rich in iron $(3.12$ and $2.69 \mathrm{mg} / \mathrm{kg})$ while apples have a low level of iron $(0.59 \mathrm{mg} / \mathrm{kg})$.

\section{Discussion}

Fruits are good sources of important nutrients such as vitamins and minerals (Table 3). They have great advantage over dietary supplements because they are cheap and easily available. Fruits have been known to reduce the risk of some diseases such as stroke, cancer, heart disease etc. (Goldberg, 2003). Fruits also possess antioxidants capacities and it is always better to consume a variety of fruits for maximum effect (Kalt, 2002). From the results shown, it can be seen that the fruits gotten from Lagos province are high in iron content. Pear, orange, banana, mango and pineapple are rich in iron content, the values ranging from $2.19-3.13 \mathrm{mg} / \mathrm{kg}$. The iron levels found in the fruits are within WHO limits. Iron is an important component of hemoglobin and intake of iron is very good to health. The highest value of copper was found in pear fruits and it had a value of $1.16 \mathrm{mg} / \mathrm{kg}$. The provisional tolerable daily intake of copper for a $60 \mathrm{~kg}$ adult is $3 \mathrm{mg} / 60 \mathrm{~kg}$. For adults, the levels of copper found in the fruits were below the PTDI level. Copper plays an important role in a number of biochemical processes. For an essential element such as zinc, the PTDI level proposed by WHO is $60 \mathrm{mg} / \mathrm{kg}$ of an adult (FAO/WHO, 1982). The content of zinc in the fruits did not pose a toxicity risk for adults. Pawpaw is particular rich in zinc $(7.7 \mathrm{mg} / \mathrm{kg})$ followed by pineapple and pears. Carrots have the lowest amount of zinc $(0.28 \mathrm{mg} / \mathrm{kg})$. Zinc is a powerful antioxidant and it necessary to boost the immune system. It is essential for many body functions.

Table 3 Concentration of mineral metals in fruit samples

\begin{tabular}{llllll}
\hline Fruits samples & $\mathrm{Zn} \mathrm{mg} / \mathrm{kg}$ & $\mathrm{Mg} \mathrm{mg} / \mathrm{kg}$ & $\mathrm{Mn} \mathrm{mg} / \mathrm{kg}$ & $\mathrm{Fe} \mathrm{mg} / \mathrm{kg}$ & $\mathrm{Copper} \mathrm{mg} / \mathrm{kg}$ \\
\hline Mango & $1.65 \pm 0.78$ & $48.9 \pm 3.29$ & $2.76 \pm 1.20$ & $2.19 \pm 0.10$ & $0.35 \pm 0.02$ \\
Tangerine & $3.14 \pm 0.21$ & $50.2 \pm 4.45$ & $1.87 \pm 0.93$ & $1.40 \pm 0.12$ & $0.40 \pm 0.05$ \\
Pear & $5.33 \pm 0.64$ & $51.5 \pm 5.02$ & $2.02 \pm 1.50$ & $3.12 \pm 0.24$ & $1.16 \pm 0.64$ \\
Pineapple & $6.60 \pm 0.73$ & $52.3 \pm 4.35$ & $8.97 \pm 1.53$ & $2.44 \pm 0.15$ & $0.44 \pm 0.01$ \\
Apple & $4.42 \pm 0.56$ & $52.2 \pm 6.25$ & $2.07 \pm 1.25$ & $0.59 \pm 0.09$ & $0.50 \pm 0.02$ \\
carrot & $0.28 \pm 0.04$ & $50.7 \pm 6.01$ & $3.77 \pm 1.50$ & $1.17 \pm 0.73$ & $0.52 \pm 0.01$ \\
Water melon & $4.86 \pm 0.54$ & $49.9 \pm 5.33$ & $3.25 \pm 1.61$ & $1.18 \pm 0.64$ & $0.63 \pm 0.05$ \\
Orange & $4.63 \pm 0.55$ & $51.3 \pm 6.71$ & $3.92 \pm 1.66$ & $2.25 \pm 0.98$ & $0.33 \pm 0.04$ \\
Paw paw & $7.71 \pm 0.89$ & $51.3 \pm 5.95$ & $2.61 \pm 1.43$ & $2.13 \pm 0.95$ & $0.46 \pm 0.2$ \\
Banana & $0.69 \pm 0.75$ & $50.2 \pm 6.32$ & $6.08 \pm 1.46$ & $2.69 \pm 0.84$ & $0.39 \pm 0.0$ \\
\hline
\end{tabular}

Note: $\mathrm{P}<0.05$

Similar results concerning heavy metals content have been reported (Table 4). Zalewski et al in 1994 analysed the content of metals in vegetables and fruits grown in the province of Siedlce. It was found that $21 \%$ and $1.7 \%$ of the 
Plant Gene and Trait 2019, Vol.10, No.1, 1-6

http://genbreedpublisher.com/index.php/pgt

sample studied exceeded the limit for cadmium and lead. Wojciechwska-Mazurek et al in 1995, determined the content of heavy metals in spices gathered in Poland and found out that the highest lead levels were found in raspberries and carrots. The levels of all the metals examined were lowest in apples and pears. This is contrary to the results of this study which found high levels of copper and iron in pears. From this research work carried out, lead concentration was highest in apples, banana and carrot. According to WHO, the PTDI for lead for an adult is $0.21 \mathrm{mg} / \mathrm{kg}$ while the PTDL is $0.025 \mathrm{mg} / \mathrm{kg}$. Lead is still within the PTDI tolerance daily limit for adults in the fruits examined, although, there is need for continuous monitoring because of children. Cadmium levels were highest in apples $(0.14 \mathrm{mg} / \mathrm{kg})$ but still within WHO PTDI limit of $60 \mu \mathrm{g} / 60 \mathrm{~kg}$ weight of an adult. The highest chromium level was also found in apples $(0.11 \mathrm{mg}$ ' $\mathrm{kg}$ ) but still within PTDI limit of $0.2 \mathrm{mg} / \mathrm{kg}$ (Gupta, 2006). Chromium is important for glucose tolerance in the body. The monitoring study carried out by Szymezak et al in 1993 on the content of $\mathrm{Pb}$ and $\mathrm{Cd}$ in fruits and vegetables found out that $\mathrm{Pb}$ ranged from $0.013-0.144 \mathrm{mg} / \mathrm{kg}$ and $\mathrm{Cd}$ from $0.0-0.042 \mathrm{mg} / \mathrm{kg}$. The values for Cd obtained in this study are higher.

Table 4 Concentration of $\mathrm{c}$ in fruit samples

\begin{tabular}{llllll}
\hline Fruits samples & $\mathrm{Cd}$ & $\mathbf{C r}$ & $\mathbf{N i}$ & $\mathbf{C o}$ & $\mathbf{P b}$ \\
\hline Mango & $0.04 \pm 0.01$ & $0.03 \pm 0.04$ & $4.32 \pm 0.09$ & $0.27 \pm 0.03$ & $0.02 \pm 0.01$ \\
Tangerine & $0.07 \pm 0.04$ & $0.04 \pm 0.03$ & $3.63 \pm 0.08$ & $0.08 \pm 0.02$ & $0.01 \pm 0.01$ \\
Pear & $0.06 \pm 0.03$ & $0.01 \pm 0.01$ & $4.14 \pm 0.07$ & $0.04 \pm 0.02$ & $0.05 \pm 0.02$ \\
Pineapple & $0.06 \pm 0.03$ & $0.02 \pm 0.01$ & $2.09 \pm 0.06$ & $0.03 \pm 0.01$ & $0.06 \pm 0.02$ \\
Apple & $0.14 \pm 0.02$ & $0.11 \pm 0.01$ & $0.73 \pm 0.14$ & $0.02 \pm 0.01$ & $0.09 \pm 0.06$ \\
Carrot & $0.03 \pm 0.02$ & $0.05 \pm 0.03$ & $3.29 \pm 0.08$ & $0.01 \pm 0.01$ & $0.12 \pm 0.02$ \\
Water melon & $0.03 \pm 0.01$ & $0.05 \pm 0.04$ & $0.37 \pm 0.06$ & $0.04 \pm 0.02$ & $0.08 \pm 0.04$ \\
Orange & $\mathrm{ND}$ & $0.05 \pm 0.03$ & $0.37 \pm 0.07$ & $0.04 \pm 0.02$ & $0.08 \pm 0.04$ \\
Paw paw & $0.02 \pm 0.01$ & $0.20 \pm 0.05$ & $0.71 \pm 0.08$ & $0.01 \pm 0.01$ & $0.07 \pm 0.03$ \\
Banana & $0.30 \pm 0.05$ & $0.03 \pm 0.02$ & $0.70 \pm 0.08$ & $0.01 \pm 0.01$ & $0.11 \pm 0.03$ \\
\hline
\end{tabular}

Note: $\mathrm{P}<0.05$

The US National Academy of Science recommended 2.5-5mg/day of manganese (National Academy of Science, 1980) and the WHO recommended 2-9mg/day for an adult (WHO, 1994). Manganese found in this study ranged from $1.87-8.97 \mathrm{mg} / \mathrm{kg}$. This is still within WHO safe limits.

Exposure of consumer and related health risks are usually expressed as provisional tolerable daily intake (PTDI) a reference value established by joint FAO/WHO (1999). The FAO/WHO has set a limit for heavy metal intake based on body weight for an average adult (60kg body weight).

PTDI for $\mathrm{Pb}, \mathrm{Cd}, \mathrm{CU} \& \mathrm{Zn}$ are $214 \mu \mathrm{g}, 60 \mu \mathrm{g}, 3 \mathrm{mg} \& 60 \mathrm{mg}$ respectively (Joint FAO/WHO expert committee on food additives, 1999).

In a study analyzing different spices, dried fruits \& nuts commonly consumed in Pakistan for heavy metals, it was found that spices exhibit high amounts of heavy metals such as lead \& cadmium while dry fruits contained lesser amounts of heavy metals.

In a study carried out by Mahdavian \& Somashekar in 2008 in determination of heavy metals in fresh fruits in Bangalone city, India, it was found out that lead was high in mango, lemon $\&$ apple fruit, cadmium was highest in mango \& banana fruit and zinc was highest in banana fruit. This is similar to this study which found a high level of lead in apple fruit.

Delibacak et al in 2002, reported high levels of heavy metals in fruits of apple, plum, pomegranate and walnut collected from Gediz river region. This is similar to this study which found a high level of lead, cadmium and copper in apple fruits. The contents of metals in the fruits analyzed decreases in the following order: $\mathrm{Mg}>\mathrm{Zn}>$ $\mathrm{Mn}>\mathrm{Ni}>\mathrm{Fer}>\mathrm{Pb}>\mathrm{Cd}>\mathrm{Cu}>\mathrm{Cr}$. 
Plant Gene and Trait 2019, Vol.10, No.1, 1-6

http://genbreedpublisher.com/index.php/pgt

\section{Conclusion}

Elevated levels of lead show the rate at which industrialization and uncontrolled urban development is occurring. The high level of lead in the fruits might be due to the presence of heavy metals in soil of plant, growing up in different locations of the city, various factors such as exhaust gas, industrial waste and waste water increase the heavy metal contamination of fruits.

Most of the analyzed fresh fruit samples collected from Lagos province are safe since the levels of cadmium, copper, chromium, zinc, lead cobalt and manganese are below the provisional tolerable daily intake for adults as established by WHO. But for children, lead value is above the provisional tolerable weekly intake of $0.025 \mathrm{mg} / \mathrm{kg}$ established by the WHO. Therefore, there is urgent need to continue the monitoring of heavy metals in fresh fruits because they are the main sources of food for adults and children.

\section{References}

Delibacek S., Elmaci O.L., Secer M., and Bodur A., 2002, Trace element and heavy metal concentrations in management, vegetables of the Gediz River region, Int. J. Water, 2: 196-211 https://doi.org/10.1504/IJW.2002.003195

Doghiem S.M., Ashraf ELMM, Alla S.A.G., Khorsthd M.A., and Fehmysm, 2004, Pesticides and heavy metals levels in Egyptian leafy vegetable \& some aromatic medicinal plants, Food additives \& Contaminants, 21(4): 323-330 https://doi.org/10.1080/02652030310001656361

FAO/WHO, 1984, Contaminants, In Codex Alimentarius vol XVII FAO/WHO Codex Alimentarius Commission, Rome

Fotakis G. and Timbrell Ja., 2006, Role of trace elements in Cd chloride uptake in hematoma cell lines, Toxicology Letters, 164(2): 97-103 https://doi.org/10.1016/j.toxlet.2005.11.016

Goldberg G., 2003, Plant Diet and Health, The report of a British Nutrition Foundation Taskforce Blackwell Science, Oxford U.K. pp.347 https://doi.org/10.1002/9780470774465

Gupta S.K., 2006, Bioderm Research: http://www.Freepatentsonline.com/20060183708. Html

ISHS, 2001, IV International Symposium on mineral nutrition of deciduous fruit crops, Heavy metal contamination in deciduous tree fruit orchards, Implication for mineral nutrient, Acta Horticulture, 564:1-2

Jabeen S., Shan M.T., Khan S., and Hayat M.Q., 2010, Determination of major \& trace elements in ten important folk therapeutic plants of Haripur Basin, Pakistan, Pakistan Journal of Medicinal Plants Research, 4(7), 559-566

Joint FAO/WHO, 1999, Expert committee on Food Additives, Summary and Conclusions, 53 ${ }^{\text {rd }}$ Meeting, Rome

Kalt W., 2002, Health functional phytochemicals of fruits, Hort. Rev., 27: 269-315 https://doi.org/10.1002/9780470650813.ch7

Kostic D., Mitic S., Zarubica A., Mitic M., Velickowvic Y., and Rendjelo Vic S., 2011, Content of Trace metals in medicinal plants \& their extract. Hemijska Industrija, 65(2): 165-170 https://doi.org/10.2298/HEMIND101005075K

National Academy of Sciences, 1980, Recommended dietary Allowances, National Academic Press, Washington, $9^{\text {th }}$ Edition

Official method of analysis (AOAC), 2000, J Association of official analytical chemist (AOAC) Washington, D.C 17 $7^{\text {th }}$ Edition

Ozgen M., Serce S. and kaya K., 2009, Phytoxcel \& Antioxidant properties of Anthocynanic Rich Morus Nigia \& Morus Rubra fruits, Scientia Horticulture, 119(3): 275-279 https://doi.org/10.1016/j.scienta.2008.08.007

Sharma K., Agrewal M \& Marshall M.F., 2009, Heavy metals in Vegetables collected from production and market sites of a tropic urban area of India food and chemical Toxicology, 47(3): 583-591 https://doi.org/10.1016/i.fct.2008.12.016

Szymczak Y., Los R.I., Regulska B., 1993, Levels of Cd \& Pb in vegetables, fruit, cereal \& soil from areas differing in the degree of industrial pollution \& from green houses, Rocz Panstw. Zakl. Hig, 44(4): 331

Wang H., CAO G., Prior R.L., 1996, Total antioxidant capacity of fruits, J. Agric Food Chem, 44: 70 https://doi.org/10.1021/jf950579y

WHO, 1997, Evaluation of certain food additives and contaminants: $46^{\text {th }}$ Report of the joint FAO/WHO expert committee on food additives, WHO Technical report series, NO. 868, pp.i- viii

WHO, 1982, Evaluation of certain food additives \& contaminants, $26^{\text {th }}$ report of the joint FAO/WHO expert committee on Food Additives, WHO, Geneva, WHO technical Report Series, No 683

WHO, 1993, Guideless for Drinking water quality Geneva

WHO, 1994, Quality Directive of Potable Water, Who, Geneva $2^{\text {nd }}$ Edition, P. 197

WHO, 1998, Quality control methods for medicinal fruit materials, Geneva 


\section{Plant Gene and Trait 2019, Vol.10, No.1, 1-6}

http://genbreedpublisher.com/index.php/pgt

WHO, 2005, Quality control methods for medicinal plant materials revised, Geneva

Wojciechowska-Mazurek M., Zawadzka T., Karlowskik, Starska K., cwiek-Ludwicka K., and Brulinska- Ostrowska E., 1995, Content of lead, Cd, Hg, Zn \& Cu in fruit from various regions of Poland, Rocz Panstw Zakl Hig, 45(1-2): 9, (In Polish)

Zalewski W., Opra Z., Syrocka K., Lipinska J., and Jaroszynska J., 1994, Value of harmful elements in fruits \& vegetable grown in the province of siedice. Rocz Panstw Zakl Hig., 45(1-2): 9, (In Polish) 